\title{
The Digital Transformation and Disruption in Business Models of the Banks under the Impact of FinTech and BigTech
}

\author{
Virginia MĂRĂCINE \\ Bucharest University of Economic Studies, Bucharest, Romania \\ virginia_maracine@csie.ase.ro \\ Oona VOICAN \\ Ministry of Transportation, Infrastructure and Communications, Bucharest, Romania \\ oona.voican@yahoo.com \\ Emil SCARLAT \\ Bucharest University of Economic Studies, Bucharest, Romania \\ emil.scarlat@ymail.com
}

\begin{abstract}
The explosive development of artificial intelligence, machine learning and big data methods in the last 10 years has been felt in the financial-banking field which has subjected to profound changes aimed at determining an unprecedented increase in the efficiency and profitability of the businesses they carry out. The tendencies of applying the concepts coming from AI, together with the continuous increase of the volume, complexity and variety of the data that the banks collect, store and process have acquired the generic names of FinTech, respectively BigTech. Five main areas exist where Fintechs and Bigtechs can provide improvements in business models for the banks: introducing specialized platforms, covering neglected customer segments, improving customer selection, reduction of the operating costs of the banks, and optimization of the business processes of the banks. We will present some of these improvements, and then we will show how the business models of the banks dramatically transform under the influence of these changes.
\end{abstract}

Keywords: Business model, FinTech, BigTech, digital transformation, disruption, artificial intelligence, machine learning.

\section{Introduction}

The development of the digital economy in the last period affects all sectors of activity, including the banks and financial sector. Within it, banks have a special role, as engines of economic growth in all sectors of the economy.

A new way of thinking is imposed on the banks through the transition to the digital economy. This process, however is not devoid of complexity. On the one hand, the financial sector and banks are causing huge changes in the way companies and other economic organizations operate and, on the other hand, this sector is undergoing dramatic changes that make the traditional concepts of banks themselves need redefining (Hadad \& Bratianu, 2019; Kostin, 2018; Rahman et al., 2018). This interdependence between the changes to which the two basic components are subject, the companies, on the one hand, and the financial-banking sector, on the other, is best illustrated by the evolution of the business models of the banks. Consequently, the financial system includes a new component - FinTech. This fundamentally changes the financial market, and technological innovation blurs the boundaries between financial products and services and subjects either authorized to offer its or actually involved in providing them (EBA, 2017). As a result, new competitive forces and dynamics emerge and develop, expanding their influence on the market shares held by different financial intermediaries. 
The main purpose of this paper is to analyze the strategies adopted by the different types of new entrants to the financial market (FinTech, BigTech and the usual financial firms) in the provision of banking services and to examine how digitization affects the business models of banks and other providers of banking services.

\section{FinTech}

PICBE $\mid 295$

Most commonly used today in the literature is the working definition of the Financial Stability Board (FSB) for FinTech as a "technologically activated financial innovation, which could result in new business models, applications, processes or products with an associated material effect on financial markets and institutions and in the provision of financial services." (FSB, 2019)

The focus of this definition is on analyzing the implications on the effects of FinTech in banks and other financial-banking institutions. It should be noted that the term FinTech refers to a wide range of software innovations applied in both existing banks and new entrants or in the process of being modernized.

A first observation made in the literature regarding the meaning of the various definitions of FinTech, as they are now understood, shows that it is perceived in relation to an innovative service, a new business model (which can be used by a regular bank or by a certain company) or a new software program used within a start-up that determines a strong imitative current in the financial industry. A second observation is that some definitions distinguish between innovation and disruption, the first leading to the improvement of pre-existing rules in an existing regulatory framework, while the second leading to the emergence and rapid development of new rules that subsequently determine dramatically changing the framework of existing regulations.

\section{BigTech}

BigTech is a generic name that is used for large technology companies active worldwide, having a relative advantage in using digital technology. BigTech companies are usually providers of web services (search engines (SEO), social networks, e-commerce etc.) for end-users on the internet and/or IT platforms or develop and maintain an infrastructure (storage and processing capabilities data) for which other regular companies provide products or services. Like FinTech companies, BigTech companies are usually automated and use agile processes for software developments, giving them multiple possibilities to quickly adapt their systems and services to the needs and wants of users.

BigTech companies have global business operations and have an extremely large customer base. They own and use a vast amount of information about their clients to provide them with the most appropriate financial services. In this way, the BigTech companies gain a decisive competitive advantage over the competition, for example compared to the traditional banks, in the provision of financial services. Many banks, financial institutions and fintech companies develop partnerships with BigTech companies, eventually becoming relevant financial service providers.

Relevant examples of BigTech companies are Google, Amazon, Facebook and Apple, known as the GAFA group. Similarly, the BAT group refers to three of the largest technology companies in China, namely Baidu, Alibaba and Tencent. In addition, some well-known traditional companies, such as Microsoft and IBM, are gradually becoming more relevant to the international financial system and may be included among BigTech companies.

\section{Literature review}


Business models are, in the last two decades, a highly popular subject of analysis, especially because they can best explain the differences that are observed between the results of different firms ( Afuah and Tucci, 2003). Theoretical and empirical studies suggest that the choice of suitable business models can lead to sustainable competitive advantages and higher financial performance for the companies that use them (Amit \& Zott, 2001; Zott \& Amit, 2007).

Initially, the notion of business model was mainly used in the field of management studies (Zott \& Amit, 2011). During that period, a business model was understood as a business strategy, which was based on the balance sheet ratios and income accounts associated with them. The own studies on banking business models appear for the first time in the early works of Amel \& Rhoades (1988) and Mehra (1996).

The structural business model is placed between the strategic and operational level in the architecture of the companies (Osterwalder, 2004). While the strategic level determines the milestones and the long-term source of a competitive advantage, the operational level shows what needs to be done to achieve the long-term objectives. (Casadesus-Masanell \& Ricart, 2010).

Unlike the operational level, the business model offers a less detailed and holistic perspective on the company. It focuses mostly on basic logic steps to be followed for creating and increasing the value of the firm. (Amit \& Zott, 2001). During the time, the business model has become a tool for analyzing companies, but also a subject that can be approached separately to be designed and innovated.

Studies on business models frequently use numerous well-established research branches, such as strategic management, information systems and management of innovation and change at firm level (Zott and al., 2011). Each of these areas of approach provides a different perspective on business models. Thus, in literature we retrieve different formulations, reflecting a kaleidoscope of views on what should actually represent a business model. We find such business models where emphasis is placed on the activities and transactions of the enterprise with stakeholders (Amit \& Zott, 2012), on its resources (Demil \& Lecocq, 2010) or its choices and results (CasadesusMasanell \& Ricart, 2010). However, many of the definitions address business models not only as a lot of specific elements, but also from the perspective of how they are interconnected and mutually influenced (Casadesus-Masanell \& Zhu, 2013). This comes mainly from the fact that the multitude of elements included in the business model is a particular combination of elements that allow a firm to create and increase the value obtained in a unique way.

The objectives pursued by studies on business models can be diverse. Thus, Baden-Fuller and Morgan (2010) identify three major reasons for building a business model: a method of classifying existing business types, a way of analysis for academic studies and a recipe for practitioners who want to reproduce and innovate successful models. However, as shown in recent literature, the approaches so far do not converge towards a common theoretical framework (Zott et al., 2011), nor can we find a dominant approach (Casadesus-Masanell \& Zhu, 2013).

Regarding the business models of banks, many papers in recent years have proposed a classification of them into three broad categories, namely: significant, intuitive and based on quantitative characteristics of classified banks. These approaches can be classified based on the methodologies used as follows:

1) Studies that use clustering to classify banks based on a set of characteristics. The clustering methodology used uses an algorithm that assigns elements (in this case banks) to the clusters so as to minimize the distance between the elements of a single cluster and to maximize the distance between the average/median/centroid of the formed clusters. Distance is a predefined 
metric that shows how similar or different the elements are, based on certain variables. These works are mostly based on the agglomerative clustering hierarchy method described by Ward (1963) or the partial clustering method based on the algorithm of Vichi and Kiers (2001).

2) Studies that use qualitative approaches to classify banks according to the business model. These studies introduce a predefined classification of the business model, based on the activities, financing and legal structure of the banks. Banks are then assigned to each of these categories based on expert judgment. For example, an author who uses such a qualitative approach is the EBA (2014b, 2015, 2016). Starting with the first group of papers using the clustering methodology, Ayadi et al. (2011) explore which variables are relevant for defining a banking business model and provide preliminary evidence on the importance of business model analysis in banking regulation and supervision.

Ayadi et al. (2011, 2012) and Ayadi \& De Groen (2014) introduce the active-passive approach and use a hierarchical clustering method based on Ward's (1963) theory to identify groups of banks with similar balance sheet characteristics. In order to take these factors into account collectively, without over-representing any particular factor, indicators were used that constitute the defining characteristics of the activity/financing of a business model in banks in terms of assets and liabilities. In (Ayadi et al., 2016), the authors obtained five types of banks based on a cluster hierarchy algorithm: concentrated retail, type I diversified retail (more trading assets and bank loans), type II diversified retail (based on mainly on debt), wholesale and investment and business practitioners have designed and used countless business models capable of describing and developing a business. Examples of such business models are Canvas by Osterwalder and Pigneur (2010), Wirtz's business model, Siemens Business Model Framework BizMo (Mütze and Gerloff, 2019) or the St Galen Management Model (SGMM).

Doleski's study (Doleski, 2015) highlights a few common elements of these business models, elements that are most influenced when disruptive factors appear, such as business digitization. The first element, the normative framework, represents the normative dimension of a business model, the elements of value and strategy, the strategic dimension. The client, the market, the revenues, activation elements, processes, partners and finances are allocated to the operational point of view (Doleski 2015, p. 13). The aforementioned elements represent the generic basic modules of a business model and appear in principle in all models, regardless of sector and activity. Taken together, these elements are the core of the integrated iOcTen business model (Doleski, 2015).

One of the best-known business model is Canvas, developed by A. Osterwalder (2004), which offers a visual representation of the business models used by strategic management. The Canvas model offers a common language, so that those who evaluate and develop different business investment alternatives can easily communicate between them and with other specialists. This model became famous especially after Apple used it to invest in innovative products that were able to become dominant in the market.

The Canvas business model structures internal processes and activities into nine categories, each of which represents a building block for the realization of goods and services. The nine categories refer to four major aspects of a business, namely: customers, supply, infrastructure and financial viability. The nine categories considered are the following: 1. Customer Segments; 2. Value Proposals; 3. Channels; 4. Customer Relationship; 5. Revenue Streams; 6. Key Resources; 7. Key Activities; 8. Key Partnership; 9. Cost Structure. Each category, in turn, is divided into components which are then completed in a grid containing the above categories. The name of the 
model comes precisely from the similarity between the final frame obtained and a canvas having different segments of different colors.

In recent years, however, the Canvas model has been replaced by other more evolved models, for example with the iOcTen business model (Doleski, 2015), which, unlike the previous model, has the advantage that it allows the integration of the ten defined characteristics, taking into account permanently the changes and transformations that take place both inside and in the environment of the company.

Figure 1 shows the basic components of this business model.

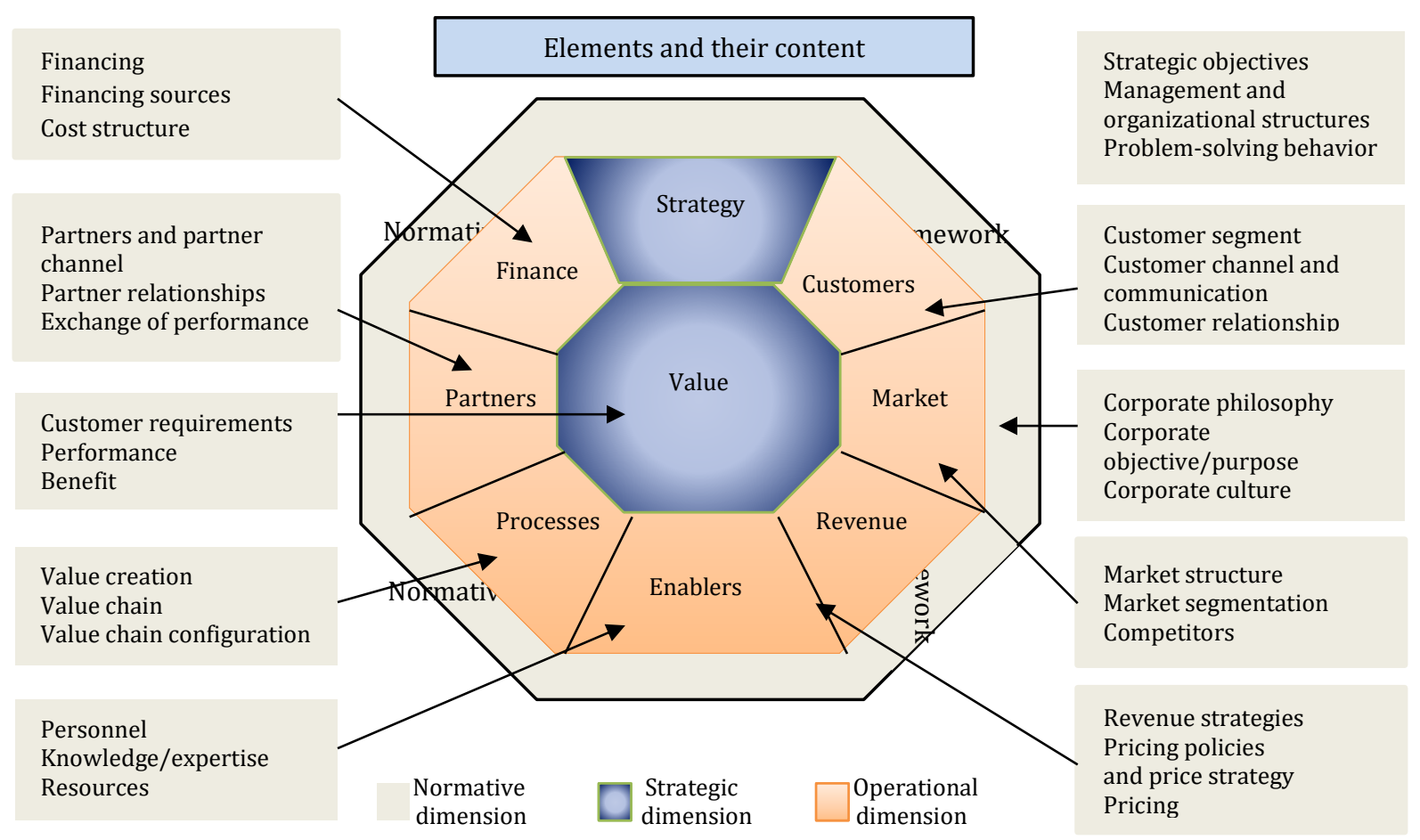

Figure 1. Components of the iOcTen model

Source: Doleski (2015)

The existence of three elements or concepts is observed: the normative dimension, the strategic dimension and the operational dimension. The normative dimension refers to the main concepts used by the model: customer, market, revenue, enablers (processes), processes, partners and finances.

The strategic dimension refers to the strategic objectives, the organizational and management structures and the problem-solving behavior. At the same time, at this level, the Philosophy of the corporation, the Purpose/objectives of the corporation and the Culture of the corporation are defined.

Operational concepts are associated with each normative concept. For example, the concept of Value includes Customer requirements, Performance and Benefit. The concept of Customer is operationalized, at the operational level, by the Customer Segment, the Channel towards the customers and the communication with them, respectively the Customer Relationship. Market 
concept is operationally associated with Market Structure, Market Segmentation and Competitors. The concept of Revenue is described by the following components: Revenue strategies, Pricing policy and price strategy and Pricing. The concept of Enablers includes: Personnel. Knowledge/expertise and Resources. The concept of Processes is described by: Value creation, Value chain and Value chain configuration. Regarding the concept of Partners, it is described with the help of the operational components Partners and partner channel, Partner relationships and Exchange of performance. Finally, the concept of Finance consists of the operational concepts of Financing, Financing sources and Cost structure.

At the level of a company, each operational concept is materialized and described with the help of advanced operations, which represent the concrete modalities that are used in each case separately to meet the requirements of the concepts used. (Kaiser \& Doleski, 2020).

\section{Methodology}

The rapid and destabilizing impact of digital technologies requires different methods that take into account the dynamic nature of the forces of change in the present era. Business models that focus on permanently improving the efficiency of the value chain are no longer sufficient. Under new conditions, customers may not simply respond to bank signals and change their decision-making and business behavior. In this context, the methods of identifying digital disruptions and their causes become very important to ensure that decisions are made to counteract them.

In order to identify the real and potential disturbances, a method is used that offers the possibility to identify and analyze in depth the disturbing factors. This method uses three major components. The first component starts from the concepts of first order and second order impact, which are related to the disruption interruption already started, which initially helps the existing business structure, but then continues to undermine it. The second important component is the disturbance assessment matrix (DAM), designed to combine several disturbing factors to identify the disturbed area. The third component is the disturbance impact assessment (DIE), a detailed analysis tool which determines the intensity of the impact of the disturbance on the main stakeholders in the respective business (Steward, B. et al., 2017).

Digital disruption takes place in successive stages whereby the initial benefits obtained by digitization are subsequently lost through continuous digitization, which changes the nature of the pre-existing service or product to establish a new state of normality. These stages can be regarded as first and second order disturbances. The concept of the impact order is well known from the business model developed by Westerman et al. (2014). They said: ,reinventing industries, replacing products or services, creating new digital businesses, reconfiguring the provision of value and rethinking value propositions" (Westerman et al. 2014, p. 78). This classification of the impact of digitization of the first and second order is done taking into account the following aspects:

Figure 2 shows the disturbance evaluation matrix (DAM).

DOI: $10.2478 /$ picbe-2020-0028, pp. 294-305, ISSN 2558-9652| Proceedings of the $14^{\text {th }}$ International Conference on Business Excellence 2020 


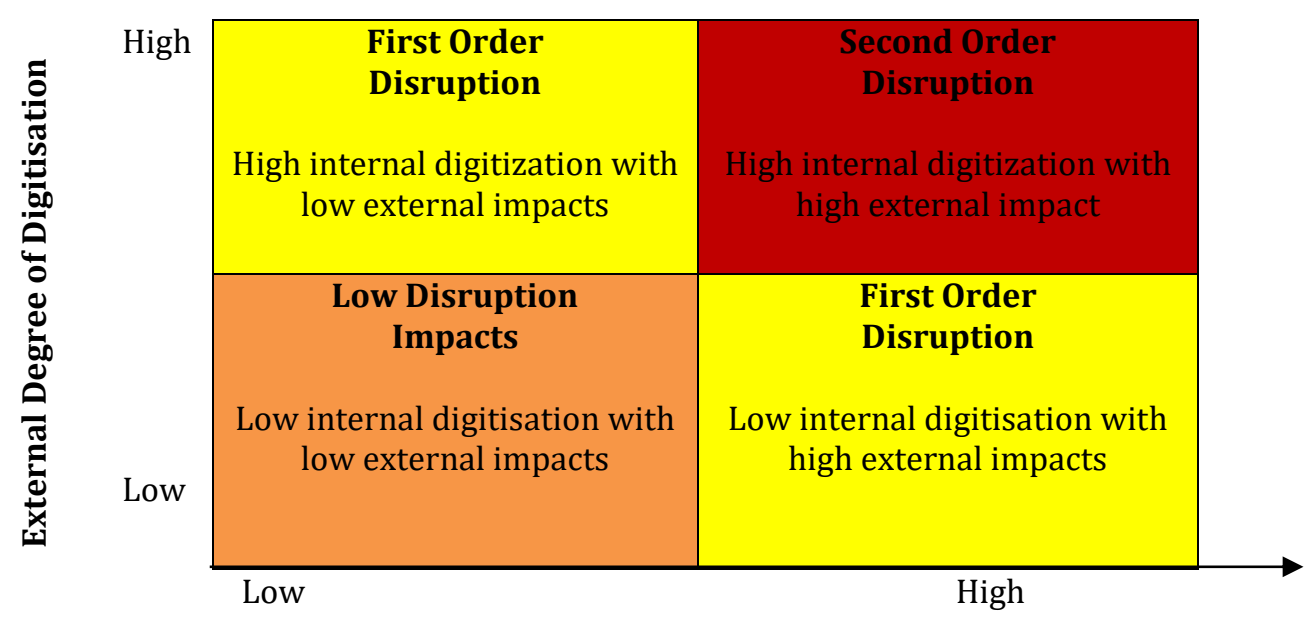

PICBE | 300

\section{Internal Degree of Digitization}

Figure 2. The disturbance evaluation matrix (DAM)

Source: B. Stewart et al. (2017)

Figure 2 gives a graphical description of the method and evaluation of the characteristics of a potential change in the position of a firm or banks due to the digitization. The impact grid is a $2 \times 2$ matrix that provides a framework for an initial classification of digital disturbances. The $\mathrm{X}$ axis measures the internal degree of digitization, while the $Y$ axis measures the external degree of digitization. The axes also refer to the four groups (presented in Table 1) with internal factors that are investors and producers and external factors that are the consumers and the public. The Disturbance Assessment Matrix (DAM) provides a means of visualizing the different facets of organizational disruption. The grid can be viewed as a combination of standard PESTLE analysis, environmental risk assessment, scenario planning and a set of competitive Porter analyzes (Porter, 2008).

Table 1. Disruption assessment matrix (DAS)

\begin{tabular}{|l|l|l|l|l|l|l|}
\hline $\begin{array}{l}\text { Domains/ } \\
\text { Stakeholders }\end{array}$ & $\begin{array}{l}\text { Legal, } \\
\text { political }\end{array}$ & $\begin{array}{l}\text { Economic } \\
\text { and } \\
\text { business }\end{array}$ & $\begin{array}{l}\text { Health and } \\
\text { Wellness }\end{array}$ & $\begin{array}{l}\text { Cultural, } \\
\text { etical and } \\
\text { moral }\end{array}$ & $\begin{array}{l}\text { Techno- } \\
\text { logical }\end{array}$ & $\begin{array}{l}\text { Environ- } \\
\text { mental }\end{array}$ \\
\hline Owners & & & & & & \\
\hline $\begin{array}{l}\text { Investors } \\
\text { intern/extern }\end{array}$ & & & & & & \\
\hline $\begin{array}{l}\text { Stock } \\
\text { markets }\end{array}$ & & & & & & \\
\hline Producers & & & & & & \\
\hline Employees & & & & & & \\
\hline Managers & & & & & & \\
\hline Consumers & & & & & & \\
\hline$\ldots$ & & & & & & \\
\hline
\end{tabular}

Source: B. Stewart et al. (2017) 
In the disturbance assessment matrix (DAM), are represented six domains that determine people's actions and behaviors (Legal and regulatory, political; Economic and business; Health and wellness; Cultural/social/ethical and moral; Technological; Environmental). The stakeholder classification is made according to their relationship with the production (supply) or consumption of goods and services. They are viewed according to two categories: internal and external.

The Digitalization Impact Evaluation (DIE) framework (Table 2) provides a segmentation of the population to assess the impact of each domain on each stakeholder group. Stakeholders are regarded as persons belonging to the categories considered. The purpose is to allow a clearer and more open framework of analysis that takes into account any given digital development.

Table 2. Digitalization impact evaluation (DIE)

\begin{tabular}{|l|l|l|l|l|l|}
\hline Impact & No impact & $\begin{array}{l}\text { Impacts } \\
\text { profitability }\end{array}$ & $\begin{array}{l}\text { Impacts } \\
\text { growth }\end{array}$ & $\begin{array}{l}\text { Impacts } \\
\text { existing } \\
\text { scale }\end{array}$ & $\begin{array}{l}\text { Severe } \\
\text { disruption } \\
\text { Impacts } \\
\text { survival }\end{array}$ \\
\hline $\begin{array}{l}\text { Owners and } \\
\text { Investors }\end{array}$ & & & & \\
\hline $\begin{array}{l}\text { Reduce the risk } \\
\text { of capital loss }\end{array}$ & & & & & \\
\hline $\begin{array}{l}\text { Improve } \\
\text { portfolio } \\
\text { performance }\end{array}$ & & & & & \\
\hline$\ldots$ & & & & \\
\hline Producers & & & & & \\
\hline $\begin{array}{l}\text { Increase } \\
\text { profitability }\end{array}$ & & & & & \\
\hline $\begin{array}{l}\text { Enhance } \\
\text { customer } \\
\text { relationships }\end{array}$ & & & & & \\
\hline$\ldots$ & & & & & \\
\hline Customers & & & & & \\
\hline $\begin{array}{l}\text { Speed of } \\
\text { delivery }\end{array}$ & & & & & \\
\hline Lower cost & & & & & \\
\hline$\ldots$ & & & & \\
\hline Public & & & & \\
\hline $\begin{array}{l}\text { Improve } \\
\text { Environmental } \\
\text { Performance }\end{array}$ & & & & \\
\hline $\begin{array}{l}\text { Reduce carbon } \\
\text { output }\end{array}$ & & & & \\
\hline$\ldots$ & & & & \\
\hline
\end{tabular}

Source: B. Stewart et al. (2017)

The impact assessment of digitization (DIE) is used together with the DAM as an initial step to determine the degree of impact that a digital innovation will have on the various stakeholder groups.

\section{Results and discussions}


The disruption caused by the FinTech and BigTech in almost all areas of finance and banking creates a pressing need for new and radical solutions. This is also true for business models.

Let us present below some of the most important disruptions that have been manifested so far in the banking field and how they are reflected in changing the structure of the business models:

\section{1) Introduction of specialized platforms}

To the extent that FinTechs focus on offering specific services and increasing the diversity of specialized lending opportunities, they can offer better portals that are successful among their customers. Such a portal can offer, in addition to regular payment transactions, a variety of other services at the clients' request, such as currency exchange or transfer of certain amounts of money to third parties. As a rule, FinTech focus on the most profitable banking services, such as managing personal accounts or SMEs, which represent about $50 \%$ of the profits made by banks (Wewege, L. \& Thomsett, M.C., 2020).

FinTech companies offer a variety of electronic payment solutions. FinTech's development has facilitated the circulation of virtual and crypto money, which was impossible using only traditional banking systems. All of these solutions are integrated into decentralized blockchain architectural structures, which have a large extension among the different categories of clients, ensuring a particularly high level of communications security. Blockchain, a decentralized and distributed file network structure, will increasingly affect financial institutions in the future. Blockchain can make things more efficient in the financial services industry. Financial institutions will use blockchain for smart contracts, digital payments, identity management, and trading shares. Since fraud and identity theft cost financial institutions billions of dollars annually, blockchain has the potential to save the industry from experiencing these significant losses.

\section{2) Covering neglected customer segments}

Traditional banks usually exclude a significant part of the population. Based on 2019 International Finance Corporation data, 45-55\% of SMEs worldwide do not have an overdraft allowance, but would benefit from one, while $21-24 \%$ although they have accessed loans, they are in very limited of different regulations. Worldwide, there are another $\$ 2.4$ trillion in credit applications. In the US, 44\% of SME lending applications were rejected. In the UK there is a funding gap of up to $£ 59$ billion. In addition, about $30 \%$ of British SMEs have failed to obtain the funding they have tried to obtain.

By offering alternative lending services, fintech companies offer innovative approaches to segments such as subprime lending, which are not served by traditional banking services. Financing sindicate Kabbage, Lendio, OnDeck and Swift Capital are some of the players who have made use of the $20 \%$ decrease in bank loans to SMEs after the 2007 and 2008 crisis. Loans for larger companies increased by about $4 \%$ in the same period. FinTech offers have grown rapidly by serving segments that are left out of traditional corporate banking channels - such as the subprime category for small businesses. By adopting FinTech and BigTech technologies, traditional banks can apply digital lending models to assess the creditworthiness of customers whose financial profiles do not comply with traditional lending rules.

\section{3) Improve customer selection}

The data held by banks are as valuable as gold, especially all data relating to transactions. The concept of Big Data has shown its full value when it began to be used in business models of banks. By combining internal data sources with other external sources, commercial banks are improving their pricing strategies, which can sometimes have very complex structures. This richness and variety of information, along with their complexity can also be used to decide how to 
classify customers and which products are most recommended for each type of activity they carry out. Data processing can also help in making credit decisions. Some of the new FinTech technologies in the US use over 2000 different data points from over 100 sources to make a credit decision.

\section{4) Reduction of the operating costs of commercial banks}

Fintech can create services, platforms and products with a small budget. Since these products are mostly made on virgin land, there are no inheritance issues, so pre-existing IT systems would have legal licensing issues. The various innovations suggested by FinTech can be used to reduce the operating costs of the respective banking system. For example, in the front-line space, virtual assistants can improve customer services, thus reducing labor costs. smart, electronic identification and optical character recognition solutions.

Standardizing and digitizing banking processes allows FinTech to sell products and services at substantially lower prices. In some cases, solutions have been used for international transactions that cost about $75 \%$ less than on traditional channels. In addition, companies such as Ripple, a large dairy manufacturer and distributor, use block chain technologies to speed up processing times for payment settlement and reduce transaction costs. Using digitized payment and block chain options, commercial banks not only increase the efficiency of their operations, but also save billions of dollars per year.

\section{5) Optimization of the business processes of the banks}

The increasingly widespread use of FinTech technology enables the automation of banking transactions, and customers can make payments using mobile phones and tablets (mobile banking). Therefore, bank employees need to play more a consultant role rather than conducting transactions directly.

According to Citigroup, the number of US bank personnel is expected to decrease by $30 \%$ by 2025 , from 2.6 million to 1.8 million people today. In Europe, personnel employed in the banking industry are expected to decrease by $38 \%$, from 2.9 million to 1.8 million. FinTech offers digital procedures that can improve the business processes of banks. For example, advanced search engines combined with automatic decision-making procedures lead to rapid credit approval.

Platforms such as the one developed by Earthport allow the settlement of international payments in real time. Finally, a platform like the one used by Ripple can encourage direct international payments, significantly reducing costs and downtime. The optimization of banking processes is one of the most disruptive changes that will affect the entire banking industry, but also its interdependence with the rest of the industries.

\section{Conclusion}

Developing suitable business models for the banks is today a top priority. Business models create the conceptual framework for the systematic realization of digital business ideas and open up new business areas, therefore, they represent the practically available toolkit for the implementation of advanced initiatives.

The FinTech makes it impossible to run a business based on conventional operations, the strictly traditional approaches used so far prove to be outdated. The advent of BigTech technologies would be both a blessing and a curse for banks and financial institutions, as it opens up new opportunities with one hand and threatens to kill existing business models with the other (Schallmo et al., 2017). 
Grater focus on well-individualized services enables FinTech and BigTech companies to provide efficient services with new technologies, including those based on artificial intelligence. Artificial intelligence algorithms play an increasing role in determining customer scoring, identifying bank frauds, or segmenting customers.

\section{References}

Afuah, A. \& Tucci, C. (2003). Internet Business Models and Strategies - Text and Cases, 2nd ed., Boston, McGrow Hill.

Amel, D. \& Rhodes, S.A. (1999). Strategic Groups in Banking. The Review of Economics and Statistics, Vol. 70, pp. $685-689$.

Amit, R. \& Zott, C. (2001). Value Creation in e-business, Strategie Management Journal, Vol. 22, No. 6/7, pp. $493-520$.

Casadesus-Masanell, R. \& Ricart, (2010). From Strategy to Business Models and onto Tactics, Long Range Planning 43 195- 215

Casadesus-Masanell, R. \& Zhu, F. (2013). Business Model Innovation and Competitive Imitation:The Case of Sponsor-Based Business Models. Strategic Management Journal 34, no. $4: 464-482$.

Demil, B., and Lecocq, X. (2010). Business model evolution: In search of dynamic consistency, Long range planning, 43 (2/3), 227-246.

Doleski, O. D. (2015). Integrated Business Model_Applying the St. Gallen Management

Concept to Business Models. Springer Essentials. Wiesbaden: Springer Gabler.

EBA (2014b). Second report on impact assessment for liquidity measures under Article 509(1)of the CRR, EBA.

EBA (2015). EBA Report on Net Stable Funding Requirements under Article 510 of the CRR EBA/Op/2015/22.

EBA (2016). EBA Report on the Leverage Ratio Requirements under Article 511 of the CRR, EBA/Op/2016/13.

FSB(2019). FinTech and market structure in financial services: Market developments and potential financial stability implications

Hadad, S., \& Bratianu, C. (2019). Dematerialization of banking products and services in the digital era. Management \& Marketing. Challenges for the Knowledge Society, 14(3), 318-337.

Kaiser, T., Doleski, O.D. (2020). Advanced Operations. Best Practices for the Focused

Establishment of Transformational Business Models, Springer Vieweg.

Kostin, K (2018). Foresight of the global digital trends. Strategic Management, 23(2), 11-19.

Lecocq X., Demil B. (2010). Business Models as a research program in strategic management: An appraisal based on Lakatos, M@n@gement, 13,4,p.214-225.

Mütze J., Gerloff A. (2020). Customer Value Co-Creation: Gemeinsam die Chancen der Digitalisierung nutzen. In: Doleski O. (eds) Realisierung Utility 4.0 Band 1. Springer Vieweg, Wiesbaden

Osterwalder, A. (2004). The Business Model Technology. A Proposition in a Design Science Approach. PhD Thesis, University of Lausanne, Swizerland.

Osterwalder, A \& Pigneur, Y. (2010). Business Model Generation, London School of Economics, April.

Porter, M.E, (2008). The Five Competitive Forces that Shape Strategy, Harvard Business Review, Jan., 86 (1), pp. 79 -83. 
Rahman, A., Rozsa, Z., \& Cepel, M. (2018). Trade credit and bank finance - evidence from the Visegrad Group, Journal of Competitiveness, 10(3), 132-148.

Schallmo, D. \& C. A. Williams \& L. Boardman (2017). Digital Transformation of Business Models - Best Practice, Enablers, and Roadmap, International Journal of Innovation Management, Vol. 21, No. 8.

Stewart B., Schatz R., Khare A. (2017). Making Sense of Digital Disruption Using a Conceptual PICBE | 305 Two-Order Model. In: Khare A., Stewart B., Schatz R. (eds) Phantom Ex Machina. Springer, Cham

Viki, M. \& Kiers, H. L.A. (2002). Factorial K-means analysis for two-way data, Computational Statistics \& Data Analysis, 37(1):49-64

Ward, Joe H., Jr, (1963). Hierarchical grouping to optimise and objective function, Journal of the American Statistical Association, 58(301), 236-244.

Wewege, L. \& Thomsett, M.C. (2020). The Digital Banking Revolution. How FinTech Companies are Transforming the Retail Banking Industry through Disruptive Financial Innovation, 3rd. Ed., De Gruyter.

Wirtz, B. W. (2019). Digital Business Models. Concepts, Models, and the Alphabet Case Study, Springer International Publishing

Zott, C. \& Amit, R. (2009). Business Model Design. An Activity System Perspective. Long Range Planning, August. 